\title{
EFEKTIVITAS MODEL PEMBELAJARAN SCIENCE TECHNOLOGY SOCIETY (STS) DISERTAI DENGAN MIND MAP (MM) UNTUK MEMBERDAYAKAN KETERAMPILAN PROSES SAINS SISWA
}

\author{
Ivayuni Listiani \\ Prodi PGSD FIP IKIP PGRI MADIUN
}

\begin{abstract}
The purpose of this study was to determine the effectiveness of a Science Technology Society model accompanied with Mind Map to empower the ability to science procces skills. This study was a quasi-experimental study. The study used a one-group pretestposttest design. The population of the study was all students of grade X of Public Senior High School 7 Surakarta in the academic year of 2013/2014. Sample was taken using cluster random sampling technique with a sample of 27 students. The instrument used was questionnaire, observation sheets, interviews, and tests. The ability to KPS data was tested with the Paired sample t-test and calculated by Ngain. The results showed the effectiveness of STS models accompanied with MM, in which it had been successful in increasing the ability to KPS with a value of Ngain of 0.54 and the result was significance at $\mathrm{p}=0.000$, making the ability belong to "medium" category. Based on the results of research and hypothesis testing, it can be concluded that STS model accompanied with MM was effective in empowering the ability to KPS of the tenth graders of Senior High School 7 Surakarta in the academic year of 2013/2014.
\end{abstract}

Keywords: Science Technology Society (STS), Mind Map (MM), Science Procces Skills

\begin{abstract}
Abstrak
Tujuan Penelitian adalah untuk mengetahui efektifitas model pembelajaran berbasis Science Technology Society disertai Mind Map untuk memberdayakan keterampilan proses sains. Penelitian ini merupakan penelitian kuasi eksperimen. Desain penelitian menggunakan one group pretest-posstest design. Populasi dalam penelitian adalah seluruh siswa kelas X SMA Negeri 7 Surakarta Tahun Pelajaran 2013/2014. Teknik pengambilan sampel dilakukan secara cluster random sampling dengan pengambilan sampel sejumlah 27 siswa. Instrumen yang digunakan adalah angket, lembar observasi, wawancara dan tes. Data kemampuan menganalisis diuji dengan uji Paired sample t-test dan dihitung dengan Ngain. Hasil penelitian menunjukan bahwa efektivitas model berbasis STS disertai MM menunjukkan peningkatan dengan kategori sedang dalam memberdayakan KPS dengan perolehan Ngain 0,54 serta hasil signifikansi sebesar $\mathrm{p}=0,000$. Berdasarkan hasil penelitian dan uji hipotesis dapat disimpulkan bahwa model STS disertai MM efektif dalam memberdayakan KPS siswa kelas X SMA Negeri 7 Surakarta Tahun Pelajaran 2013/2014.
\end{abstract}

Kata Kunci: Science Technology Society (STS), Mind Map (MM), Keterampilan Proses Sains 


\section{A. Pendahuluan}

\begin{tabular}{lcr}
\multicolumn{1}{c}{ Era } & globalisasi & yang \\
berkembang & semakin & pesat \\
membawa & perubahan & yang \\
signifikan & disegala & bidang \\
kehidupan & terutama pada & bidang
\end{tabular}
pengetahuan. Pesatnya ilmu pengetahuan mulai dioptimalkan melalui pemanfaatan manusia sebagai sumber daya yang dapat dimanfaatkan dalam berbagai sisi kehidupan. Pemanfaatan manusia sebagai sumber daya dalam persaingan global dilakukan dengan mengaplikasikan ilmu pengetahuan dalam bidang teknologi. Seperti yang kita rasakan sekarang aplikasi dari ilmu pengetahuan yang berkembang juga meningkatkan kemajuan teknologi yang semakin kompleks. Kemajuan teknologi yang semakin kompleks merupakan salah satu perubahan dalam era globalisasi. Kemajuan teknologi dan informasi yang berkembang semakin pesat mendorong manusia untuk dapat memanfaatkan dan menguasainya dengan baik dan tepat guna. Penguasaan teknologi yang baik dan tepat guna dapat dilakukan dengan berbagai cara, salah satunya melalui pendidikan.

$$
\text { Pendidikan menurut }
$$

Undang Undang No.20 Tahun 2003 pasal 1 merupakan usaha sadar dan terencana untuk mewujudkan suasana belajar dan proses pembelajaran agar peserta didik secara aktif mengembangkan potensi dirinya untuk memiliki kekuatan spiritual keagamaan, pengendalian diri, kepribadian, kecerdasan, akhlak mulia, serta ketrampilan yang diperlukan dirinya, masyarakat, bangsa dan negara. Suasana belajar dan proses pembelajaran yang sedemikian rupa dapat diwujudkan dalam kegiatan belajar mengajar. Kegiatan belajar mengajar dirancang dan dilakukan dengan sebaik-baiknya sesuai dengan kompetensi dasar dan indikator agar tujuan pembelajaran dapat tercapai. Pencapaian tujuan pembelajaran secara maksimal mendasari betapa pentingnya memberdayakan proses dalam pembelajaran, khususnya dalam pembelajaran IPA.

Pembelajaran IPA diarahkan untuk mencari tahu melalui serangkaian proses sehingga dapat membantu siswa untuk memperoleh pemahaman yang lebih mendalam. Biologi merupakan salah satu bagian dari IPA, oleh karenanya pembelajaran biologi seharusnya mengacu pada hakikat biologi sebagai ilmu sains, yang terdiri dari dari hands on, minds on dan hearts on activities agar pembelajaran biologi tidak kehilangan ruhnya sebagai sains (Suciati, 2011). Hands on atau keterampilan merupakan kegiatan yang harus dilakukan siswa dalam pembelajaran seperti mengamati, mengelompokkan, membuat rumusan masalah, membuat hipotesis, mengkomunikasikan, mengiterpretasikan, dan lain sebagainya merupakan proses yang harus diberdayakan dalam pembelajaran biologi agar siswa dapat mencapai konsep-konsep, fakta, teori sebagai 
produk sains atau minds on sehingga siswa dapat memperoleh sikap-sikap ilmiah atau hearts on seperti jujur, teliti, bekerja sama, menghargai dan lain sebagainya dalam pelaksanaan pembelajaran. Tujuan pembelajaran Biologi di sekolah sesuai dengan Permendiknas No. 22 Tahun 2011 adalah untuk memperoleh kompetensi dasar ilmu pengetahuan dan teknologi serta membudayakan berpikir ilmiah secara kritis, kreatif dan mandiri (BSNP, 2011). Berkaitan dengan tujuan pembelajaran di atas dapat disimpulkan bahwa pembelajaran mengharuskan para guru untuk memberikan pengalaman lebih dalam pembelajaran.

$$
\text { Pembelajaran biologi }
$$
seharusnya lebih memberdayakan pada proses karena melalui proses pembelajaran siswa akan memperoleh ilmu pengetahuan yang lebih bermakna dan dapat mengembangkan Keterampilan Proses Sains (KPS) serta kemampuan berpikirnya. KPS menurut Rustaman et al. (2005) merupakan keterampilan proses yang melibatkan keterampilanketerampilan kognitif atau intelektual, manual, dan sosial. Keterampilan kognitif atau intelektual terlibat karena siswa menggunakan pikirannya dalam melakukan proses. Keterampilan manual terlibat ketika siswa menggunakan alat dan bahan, pengukuran, penyusunan atau perakitan alat dalam melakukan proses. Keterampilan sosial terlibat dalam melaksanakan kegiatan belajar mengajar karena siswa berinteraksi dengan sesama untuk mendiskusikan hasil pengamatan. Penerapan KPS menekankan adanya keterlibatan fisik dan mental intelektual siswa yang dapat digunakan untuk melatih dan mengembangkan kecakapan berpikir siswa. KPS dapat dikembangkan melalui pemberian pengalaman belajar secara langsung.

$$
\text { Pengalaman belajar dapat }
$$

dibentuk melalui serangkaian proses pembelajaran, dimana pembelajaran seharusnya tidak terpaku pada konsep saja melainkan juga pada aplikasi dari konsep tersebut agar pembelajaran lebih bermakna. Pembelajaran seharusnya berkaitan dengan permasalahan yang ada dalam kehidupan sehari-hari supaya siswa dapat mengkonstruk pengetahuannya melalui pengalaman belajar. Hal ini sejalan dengan pendapat Vico dalam Poedjiadi (2005) yang menyatakan bahwa manusia dikaruniai kemampuan untuk membangun atau mengkonstruk pengetahuan setelah berinteraksi dengan lingkungannya. Pembelajaran tersebut sejalan dengan teori belajar Ausubel yang menjelaskan tentang proses dikaitkannya informasi baru pada konsep-konsep relevan yang terdapat dalam struktur kognitif siswa untuk dapat memberikan penyelesaian nyata dari permasalahan yang nyata (Trianto, 2010). Konsep yang diberikan yang disertai dengan aplikasi secara langsung akan memberikan pengalaman 
belajar pada siswa sehingga siswa dapat memahami konsep pembelajaran dengan baik. Pembentukan struktur kognitif melalui aplikasi secara langsung memerlukan strategi-strategi yang dapat diberdayakan oleh pendidik, sehingga diperlukan pendidik yang mempunyai kompetensi sebagai seorang pendidik.

Undang Undang Guru dan

Dosen No. 14 Tahun 2005 menyatakan bahwa guru profesional adalah guru yang mempunyai: 1) kompetensi paedagogik seperti merencanakan dan melaksanakan evaluasi pembelajaran; 2) kompetensi profesional seperti penguasaan materi subjek, memahami kurikulum dan perkembangannya, pengelolaan kelas, memiliki wawasan tentang inovasi pendidikan, penggunaan strategi, media, dan sumber belajar; 3) kompetensi kepribadian seperti tauladan, evaluasi kinerja sendiri dan menerima kritik; 4) kompetensi sosial seperti berkomunikasi, berkontribusi terhadap pengembangan pendidikan dan memanfaatkan ICT. Berdasarkan tuntutan tersebut guru dituntut untuk mampu menciptakan pembelajaran yang mendorong siswa aktif dalam pembelajaran melalui serangkaian proses.

$\begin{array}{lcr}\text { Fakta } & \text { di lapangan } \\ \text { pembelajaran } & \text { biologi } & \text { masih } \\ \text { berorientasi pada produk dan }\end{array}$

kurang mengembangkan proses belajar yang inovatif. Proses pembelajaran belum mengakomodasikan siswa untuk terlibat secara aktif dalam pembelajaran serta penggunaan bahan ajar dalam pembelajaran masih berupa buku dari sekolah dan LKS yang diperoleh dari penerbit sehingga siswa terkesan pasif. Kepasifan siswa berdampak pada kurang tertariknya siswa dalam kegiatan pembelajaran yang menyebabkan rendahnya KPS siswa dalam berkomunikasi untuk mengungkapkan apa yang kurang dimengerti sehingga siswa masih kesulitan dalam memecahkan soal yang mempunyai tingkatan C4-C6. Rendahnya kemampuan siswa dalam memecahkan soal dikarenakan dalam pembelajaran kurang memberdayakan science literacy siswa. Chabalengula et al. (2008) menyatakan bahwa pendidikan harus mempromosikan pembangunan literasi ilmiah antara siswa dengan memberikan representasi yang seimbang dari banyak aspek literasi ilmiah.

Hasil Trends in International Mathematics and Science Studies/TIMSS (2011) menunjukkan bahwa hasil sains Indonesia berada pada urutan ke-40 dari 42 negara dengan nilai rata-rata sebesar 406. Hasil serupa juga ditunjukkan dalam studi Programme for International Student Assessmentl PISA (2012) dimana skor Indonesia kembali turun menjadi 382 dan menduduki peringkat ke-64 dari 65 negara. Keadaan tersebut mengindikasikan rendahnya kemampuan anak Indonesia dalam kemampuan mengidentifikasi masalah ilmiah, 
menggunakan fakta ilmiah, memahami sistem kehidupan, dan memahami penggunaan peralatan sains (Pusat Penilaian Pendidikan Balitbang Kemendikbud, 2011).

Hasil observasi di SMA Negeri 7 Surakarta berkaitan dengan Standar Nasional Pendidikan (SNP) menunjukkan bahwa masih terdapat GAP antara kontribusi dan implementasi pada beberapa standar. Standar yang memiliki ketercapaian terendah yaitu standar proses, hal ini dikarenakan masih adanya proses pembelajaran yang belum terpenuhi dengan baik. Hasil analisis kebutuhan menunjukkan bahwa proses pembelajaran biologi di SMA Negeri 7 Surakarta belum mengoptimalkan keterlibatan aktif siswa dalam pembelajaran. Siswa hanya diberikan materi, merangkum dan mengerjakan latihan soal dalam Lembar Kerja Siswa (LKS). Pembelajaran biologi yang kurang melibatkan keaktifan siswa mengakibatkan siswa cenderung pasif dalam pembelajaran sehingga keterampilan siswa dalam berproses kurang dikembangkan secara optimal.

Berdasarkan analisis SNP diperoleh bahwa GAP tertinggi adalah standar proses yaitu sebesar 1,85. Hal ini mengindikasikan bahwa masih ada kekurangan dalam pelaksanaan proses pembelajaran di SMA Negeri 7
Surakarta. Berdasarkan hasil analisis kebutuhan menunjukkan bahwa proses pembelajaran biologi di kelas X kurang mengaktifkan peran siswa dalam mengembangkan KPS, siswa belum diarahkan untuk berproses sesuai dengan hakikat pembelajaran biologi sebagai pembelajaran sains. Kondisi pembelajaran yang belum mengaktifkan peran aktif siswa mengakibatkan siswa mengetahui berbagai konsep tanpa didukung dengan penerapan dari konsep yang telah dipelajari sehingga menyebabkan kurangnya science literacy siswa. Science literacy penting untuk dikembangkankan dalam pembelajaran karena merupakan suatu kemampuan dan sikap untuk memahami, mengkomunikasikan, serta menerapkan pengetahuan yang dimiliki dalam memecahkan masalah yang ada di lingkungan (Toharudin, Hendrawati, dan Rustaman, 2011).

Science Technology Society (STS) merupakan salah satu model pembelajaran yang dapat meningkatkan literacy science dikarenakan dalam pembelajarannya mengkaitkan antara ilmu pengetahuan dan teknologi dengan permalahan yang ada di masyarakat. Model pembelajaran dirancang dengan mengkolaborasikan antara model pembelajaran STS disertai Mind Map (MM) agar memberikan warna lain dalam skenario pembelajaran yang diharapkan dapat memudahkan siswa dalam memahami konsep dan memberikan motivasi siswa untuk tertarik dalam mengikuti kegiatan pembelajaran. Buzan (2010) menyatakan bahwa $M M$ 
merupakan suatu cara mencatat yang kreatif, efektif dan secara harfiah akan memetakan pikiranpikiran. $M M$ merupakan teknik pemetaan pikiran untuk memepermudah siswa dalam memahami materi pembelajaran dengan memaksimalkan kerja otak. Pembelajaran melalui STS disertai $M M$ dilakukan dengan sintaks pendahuluan, pembentukan konsep, aplikasi konsep, pemantapan konsep dengan $M M$, dan penilaian.

Penggunaan model

pembelajaran STS disertai $M M$ diharapkan dapat meningkatkan ketertarikan siswa dalam mengikuti proses pembelajaran sehingga siswa dapat memberdayakan KPS. Adanya keterlibatan siswa dalam menciptakan pengalaman belajarnya melalui keterampilan proses akan memudahkan siswa dalam memahami konsep pembelajaran. Hal ini sejalan dengan teori belajar konstruktivis yang menekankan pada penguasaan konsep pembelajaran yang dibentuk oleh siswa melalui pengalaman belajar. Keterlibatan siswa dalam pembelajaran yang memberdayakan KPS melalui model pembelajaran berbasis STS disertai $M M$ diharapkan dapat digunakan sebagai bekal dalam penyelesaian masalah yang ada (Carrol, 1989).

Berdasarkan uraian pada latar belakang di atas, judul penelitian adalah: "Efektivitas Model Pembelajaran Science Technology Society (STS) disertai Mind Map (MM) untuk Memberdayakan Keterampilan Proses Sains (KPS) Siswa".

\section{B. Metode Penelitian}

Penelitian dilaksanakan di SMA Negeri 7 Surakarta kelas X semester genap tahun pelajaran 2013/2014. Sampel dalam penelitian diambil dari kelas $\mathrm{X}$ yang terdiri dari 7 kelas kemudian dilakukan pemilihan secara cluster random sampling dan diambil 1 kelas, yaitu kelas X-IPA 1 sebagai kelas eksperimen dengan membandingkan hasil pretest dan Posttest. Penelitian dilakukan dengan menggunakan metode eksperimen semu (Quasi exsperimental research). Metode eksperimen semu digunakan karena banyak dari subjek penelitian yang tidak dapat dikontrol atau dikendalikan (Darmadi, 2011). Desain penelitian yang digunakan yaitu One Group Pretest-Posttest Design dimana dalam desain kelompok atau kelas dipilih secara random sebanyak satu kelas. Kelas yang terpilih adalah kelas diberikan perlakuan atau treatment berupa model pembelajaran STS disertai $M M$. Data yang diperoleh kemudian diolah dan dianalisis untuk mengetahui ada tidaknya pengaruh efektivitas model pembelajaran STS disertai $M M$ terhadap KPS siswa kelas X SMA Negeri 7 Surakarta. Desain penelitian ini disajikan pada Tabel 1 berikut:

Tabel 1. Rancangan Penelitian One Group Pretest-Posttest Design (Syaodih Sukmadinata, 2012). 


\begin{tabular}{lccc}
\hline Kelompok & $\begin{array}{c}\text { Pra } \\
\text { test }\end{array}$ & $\begin{array}{c}\text { Treat } \\
\text { ment }\end{array}$ & $\begin{array}{c}\text { Pasca } \\
\text { test }\end{array}$ \\
\hline $\mathrm{A}$ & $\mathrm{O}_{1}$ & $\mathrm{X}_{1}$ & $\mathrm{O}_{2}$ \\
\hline
\end{tabular}

Keterangan:

$\mathrm{O}_{1}$ : Test awal yang diberikan.

$\mathrm{X}$ : Perlakuan yang diberikan yaitu model pembelajaran STS disertai $M M$.

$\mathrm{O}_{2}$ : Tes akhir yang diberikan.

Variabel dalam penelitian terdiri dari variabel bebas dan variabel terikat. Variabel bebas merupakan variabel yang mempengaruhi variabel terikat dalam suatu treatment (Arikunto, 2006). Variabel bebas dalam penelitian adalah model pembelajaran STS disertai $M M$. Variabel terikat merupakan variabel yang dipengaruhi oleh variabel bebas sebagai akibat dari suatu treatment (Arikunto, 2006). Variabel terikat dalam penilitian ini adalah KPS.

Teknik pengumpulan data yang digunakan dalam penelitian adalah teknik tes dan non tes. Teknik tes digunakan untuk mengambil data KPS dan hasil belajar ranah kognitif. Pertanyaan dalam tes dapat berupa tes tertulis maupun lisan. Tes yang akan digunakan pada penelitian berupa tes obyektif yaitu bentuk pilihan ganda. Teknik non tes berupa dokumentasi, observasi, dan angket. Teknik dokumentasi dilakukan dengan mengumpulkan data dan berkas yang dibutuhkan kemudian menelaah dokumen yang diperoleh yang berkaitan dengan obyek penelitian (Riduwan, 2004). Fungsi dari dokumentasi pada penelitian adalah untuk mendapatkan nilai Ujian Akhir Semester kelas $\mathrm{X}$ semester 1 tahun pelajaran 2013/2014 mata pelajaran biologi yang digunakan untuk uji keseimbangan. Observasi atau pengamatan digunakan untuk mengamati perilaku dan sikap individu yang muncul dalam proses kegiatan pembelajaran. Observasi dapat mengukur proses pembelajaran secara eksternal, misalnya tingkah laku siswa, keaktifan siswa, kegiatan diskusi, partisipasi siswa, serta interaksi antar siswa. Observasi harus dilakukan pada saat proses berlangsung (Sudjana, 2010). Teknik non tes melalui observasi digunakan untuk mengukur hasil belajar ranah psikomotor dan ranah afektif. Penilaian dilakukan oleh observer dengan memberikan checklist $(\sqrt{ })$ pada lembar observasi. Skala yang digunakan pada lembar observasi adalah skala

Numerical Rating Scale dengan skala yang bernilai 1 sampai dengan 4 (Widoyoko, 2009). Angket digunakan untuk mengambil data pendukung berupa hasil belajar ranah psikomotor dan afektif. Pengukuran data pendukung menggunakan angket dalam bentuk pilihan ganda yaitu bentuk angket dimana pengisi angket tinggal memberi tanda silang pada pilihan jawaban yang dianggap paling benar. Alternatif jawaban tiap item ada empat. Pemberian skor tiap item pernyataan menurut skala Likert dapat dilihat pada tabel 2 berikut: 
Tabel 2. Skor Penilaian Berdasarkan Skala Likert (Sugiyono, 2010).

\begin{tabular}{lcc}
\hline Pernyataan Sikap & \multicolumn{2}{c}{ Nilai } \\
& $\begin{array}{c}\text { Pernyata } \\
\text { an positif an }\end{array}$ & $\begin{array}{c}\text { Pernyata } \\
\text { negatif }\end{array}$ \\
\hline Sangat Setuju (SS) & 4 & 1 \\
Setuju (S) & 3 & 2 \\
Tidak Setuju (TS) & 2 & 3 \\
Sangat Tidak & 1 & 4 \\
Setuju (STS) & & \\
\hline
\end{tabular}

Instrumen penelitian dalam penilaian KPS berupa tes pilihan ganda, kemampuan kognitif yang digunakan berupa tes objektif, sedangkan untuk tes objektif sebelum digunakan untuk mengambil data penelitian, diujicobakan terlebih dahulu untuk mengetahui kualitas soal. Penguajian kualitas soal dilakukan untuk mengetahui validitas, reliabilitas, daya beda dan taraf kesukarannya.

1. Uji validitas

Validitas merupakan mutu penting dari setiap tes. Validitas merupakan ketepatan dan kecermatan suatu instrumen dalam melakukan fungsi ukurnya (Darmadi, 2011). Valid berarti instrumen tersebut dapat digunakan untuk mengukur apa yang seharusnya diukur. Uji validitas dalam penelitian ini digunakan untuk mengukur instrumen yang berbentuk tes hasil belajar pada ranah kognitif. Validitas terdiri dari tiga yaitu validitas isi, validitas konstruk dan validitas butir soal. Validitas butir soal dan butir angket dihitung dengan menggunakan rumus koefisien Product moment dari Karl Pearson (Arikunto, 2010). rXY $\frac{N \sum X Y-\left(\sum X\right)\left(\sum Y\right)}{\left.\sqrt{\left\{N \sum X^{2}-\left(\sum X\right)^{2}\right\}\left\{N \sum Y^{2}-\left(\sum Y\right)^{2}\right.}\right\}}$ Keterangan :

$\mathrm{rXY}$ : koefisien korelasi antara $\mathrm{x}$ dan y $\mathrm{N}$ : cacah subyek yang dikenai tes (instrumen)

$\mathrm{X} \quad$ : skor untuk butir ke-i

Y : skor total (dari subyek try out) Jika harga ruv < $\mathrm{r}$ tabel, maka korelasi tidak signifikan sehingga item pertanyaan dikatakan tidak valid. Sebaliknya, jika ruv > $r$ tabel maka item pertanyaan dinyatakan valid. Acuan penilaian validitas dari butir soal atau item menurut Riduwan (2004) adalah:

$0,8-1,00 \quad$ : Sangat Tinggi (ST)

$0,6-0,799$ : Tinggi (T)

0,4-0,599: Cukup (C)

0,2-0.399 : Rendah (R)

0,00- 0,199 : Sangat Rendah (SR)

Hasil uji validitas tes try out soal di kelas X SMA Negeri 2 Karanganyar secara ringkas disajikan pada Tabel 3.

Tabel 3. Rangkuman Uji Validitas Tes

\begin{tabular}{lccc}
\hline \multicolumn{1}{c}{ Instrumen Penelitian } & Jumlah & \multicolumn{2}{c}{ Keputusan Uji Validitas } \\
\cline { 3 - 4 } & Item & Valid & Invalid \\
\hline Keterampilan Proses Sains & 20 & 20 & 0 \\
Hasil belajar Kognitif & 50 & 44 & 6 \\
Hasil belajar Afektif & 24 & 24 & 0 \\
\hline
\end{tabular}


Berdasarkan Tabel 3 dapat diketahui bahwa hasil perhitungan uji validitas tes keterampilan proses sains dan hasil belajar afektif menunjukkan semua jumlah item valid, sedangkan tes kognitif terdapat 6 item tidak valid.

\section{Reliabilitas}

$$
\text { Reliabel artinya dapat }
$$
dipercaya. Suatu tes dikatakan mempunyai taraf reliabilitas yang tinggi jika tes tersebut dapat memberikan hasil yang tetap apabila diteskan berulang-ulang. Riduwan (2004) menyatakan bahwa reliabilitas instrumen tes yang memberikan jawaban yang benar bernilai 1 dan jawaban salah bernilai 0 . Untuk menghitung tingkat reliabilitas tes hasil belajar, digunakan rumus Kuder Richason (KR-20) untuk tes hasil kognitif karena tes berbentuk pilihan ganda. Berikut ini merupakan rumus dari Kuder Richardson (KR-20) :

$$
\left.r=\left(\frac{k}{k-1}\right)^{(S} \frac{\left.2^{-} \sum^{p q}\right)}{S^{2}}\right)
$$

Dengan:

$$
\begin{aligned}
& \text { r11 : Reliabilitas test secara } \\
& \text { keseluruhan } \\
& \mathrm{p} \quad \text { : Proporsi subjek yang } \\
& \text { menjawab item dengan benar } \\
& \text { q : Proporsi subjek yang } \\
& \text { menjawab item dengan benar } \\
& (\mathrm{q}=1-\mathrm{p})
\end{aligned}
$$

Dengan ketentuan koefisien korelasi yang dapat dilihat pada tabel 4 .

Tabel 4. Koefisien Korelasi

\begin{tabular}{cc}
\hline $\begin{array}{c}\text { Koefisien } \\
\text { korelasi }\end{array}$ & Kriteria realibilitas \\
\hline $0,81<\mathrm{r}<1,00$ & Sangat tinggi \\
$0,61<\mathrm{r}<0,80$ & Tinggi \\
$0,41<\mathrm{r}<0,60$ & Cukup \\
$0,21<\mathrm{r}<0,40$ & Rendah \\
$0,00<\mathrm{r}<0,21$ & Sangat rendah \\
\hline
\end{tabular}

Kriteria: Apabila r11 > rtabel maka soal tersebut reliabel.

Hasil uji reliabilitas tes tryout soal analitis di kelas X SMA Negeri 2 Karanganyar secara ringkas disajikan pada Tabel 5.

Tabel 5. Rangkuman Uji Reabilitas Hasil Tes Tryout Siswa

\begin{tabular}{lccc}
\hline \multicolumn{1}{c}{ Instrumen Penelitian } & $\begin{array}{c}\text { Jumlah } \\
\text { Item }\end{array}$ & Indeks Reabilitas & $\begin{array}{c}\text { Keputusan Uji } \\
\text { Reabilitas }\end{array}$ \\
\hline Keterampilan Proses Sains & 20 & 0,831 & Sangat Tinggi \\
\hline Hasil belajar Kognitif & 50 & 1,018 & Sangat Tinggi \\
\hline Hasil belajar Afektif & 24 & 0,910 & Sangat Tinggi \\
\hline
\end{tabular}

\section{Berdasarkan tabel 5 hasil}

uji reliabilitas instrumen

pembelajaran cukup dan reliabel untuk digunakan, yang dibuktikan dengan indeks reliabilitas yang masuk pada kriteria sangat tinggi.

\section{Indeks Kesukaran}

Taraf kesukaran suatu item butir soal dapat diperoleh dari banyaknya siswa yang menjawab benar. Soal yang baik adalah soal yang tidak terlalu mudah dan juga tidak terlalu sukar atau bisa 
dikatakan bahwa soal yang baik adalah soal dengan kategori sedang. Untuk mengukur tingkat kesukaran tiap butir soal digunakan rumus :

$$
\mathrm{P}=\frac{\mathrm{B}}{\mathrm{J}_{\mathrm{s}}}
$$

Keterangan :

$\mathrm{P}$ : tingkat kesukaran item soal

B : Jumlah siswa yang menjawab benar
Js : jumlah seluruh siswa yang mengikuti tes

Kriteria tingkat kesukaran soal :

Soal dengan $0,00<0,30$ : sukar

Soal dengan $0,30<0,70$ : sedang

Soal dengan 0,70 1,00: mudah

(Arikunto, 2010)

Hasil uji taraf kesukaran tes try out di kelas X SMAN 2 Karanganyar secara ringkas disajikan pada Tabel 6.

Tabel 6. Rangkuman Uji Taraf Kesukaran Hasil Tes Try Out Siswa

\begin{tabular}{lccccc}
\hline \multirow{2}{*}{ Instrumen Penelitian } & \multirow{2}{*}{$\begin{array}{c}\text { Jumlah } \\
\text { Soal }\end{array}$} & $\begin{array}{c}\text { Jumlah } \\
\text { Item }\end{array}$ & \multicolumn{2}{c}{ Keputusan Uji Validitas } \\
\cline { 4 - 6 } & & dipakai & Sukar & Sedang & Mudah \\
\hline Keterampilan Proses Sains & 20 & 20 & 5 & 10 & 5 \\
Hasil belajar Kognitif & 50 & 40 & 10 & 20 & 10 \\
\hline
\end{tabular}

Berdasarkan Tabel 6 hasil

uji taraf kesukaran tes diperoleh hasil untuk instrumen KPS terdapat 5 soal yang masuk kategori sukar, 10 soal yang masuk kategori sedang, dan 5 soal yang masuk kategori mudah. Taraf kesukaran pada hasil belajar ranah kognitif 10 soal yang masuk kategori sukar, 20 soal yang masuk kategori sedang, dan 10 soal yang masuk kategori mudah.

\section{Daya Pembeda Soal}

Daya pembeda soal merupakan kemampuan suatu soal yang berfungsi untuk mnengktegorikan kemampuan antara siswa yang pandai dengan yang berkemampuan kurang. Suatu soal yang mempunyai daya pembeda tinggi menandakan bahwa soal tersebut dapat membedakan siswa yang pandai dengan yang kurang pandai. Rumus yang digunakan untuk menentukan daya pembeda adalah:

$$
D={ }_{A A}{ }_{I B}=P_{A} A^{-P} P_{B}
$$

\section{Keterangan :}

J : Jumlah peserta tes

$\mathrm{J}_{\mathrm{A}}$ : banyaknya peserta kelompok atas
$\mathrm{J}_{\mathrm{B}}$ : banyaknya peserta kelompok bawah

Y : skor total (dari subyek uji coba)

BA : banyaknya peserta kelompok atas yang menjawab soal dengan benar

BB : banyaknya peserta kelompok bawah yang menjawab soal dengan benar

— : proporsi peserta kelompok atas yang menjawab soal dengan benar 
$\mathrm{B}_{\mathrm{B}}$

: proporsi peserta kelompok

bawah yang menjawab soal dengan benar

Klasifikasi daya pembeda menurut Arikunto (2010) adalah:

D: $0.00-0.20$ : jelek (poor)

D: $0.20-0.40$ : cukup (satisfactory)

D: $0.40-0.70$ : baik (good)

D: $0.70-1.00$ : baik sekali (excellent)

D: Negatif : semua butir soal yang mempunyai $\mathrm{D}$ negatif dibuang
Butir soal yang dipakai adalah yang mempunyai nilai $\mathrm{D}$ baik dengan indeks $0.40-0.70$ dan baik sekali dengan indeks $0.70-1.00$.

Hasil uji taraf kesukaran tes tryout di kelas $\mathrm{X}$ SMA $\mathrm{N} 2$ Karanganyar secara ringkas disajikan pada Tabel 7.

Tabel 7 Rangkuman Uji Daya Pembeda Hasil Tes Try Out Siswa

\begin{tabular}{lccccccc}
\hline \multirow{2}{*}{ Instrumen Penelitian } & \multirow{2}{*}{ Jumlah } & Jumlah & \multicolumn{4}{c}{ Keputusan Uji Validitas } \\
\cline { 2 - 8 } & Soal & $\begin{array}{c}\text { Item } \\
\text { dipakai }\end{array}$ & Jelek Cukup Baik & $\begin{array}{c}\text { Baik } \\
\text { sekali }\end{array}$ & Negatif \\
\hline Keterampilan Proses Sains & 20 & 20 & 7 & 8 & 5 & 0 & 0 \\
Hasil belajar Kognitif & 50 & 40 & 25 & 19 & 3 & 0 & 3 \\
\hline
\end{tabular}

Analisis data penelitian efektivitas model $S T S$ disertai $M M$ menggunakan analisis inferensial. Analisis statistik inferensial digunakan untuk mengetahui efektivitas model pembelajaran biologi berbasis STS disertai $M M$ dalam memberdayakan KPS. Analisis statistik inferensial dilakukan dengan uji Paired sample $t$ test (uji $\mathrm{t}$ berpasangan) menggunakan bantuan program analisis SPSS 18 yang didahului dengan uji prasyarat yaitu uji homogenitas dan uji normalitas. uji homogenitas menggunakan Levene's, uji hipotesis menggunakan Wilcoxon dan untuk mengetahui efektivitas diuji degan Ngain.

\section{Hasil}

Hasil uji efektivitas dari produk model pembelajaran berbasis STS disertai $M M$ diperoleh dari data KPS melalui uji hipotesis dan nilai peningkatan gain ternormalisasi $\left(N_{\text {gain }}\right)$. Hasil uji hipotesis data KPS disajikan pada Tabel 8 Hasil uji Gain dan Ngain KPS disajikan pada Tabel 9.

Tabel 8. Hasil Uji Hipotesis KPS

\begin{tabular}{|c|c|c|c|c|}
\hline Uji & Jenis Uji & Hasil & Keputusan & Kesimpulan \\
\hline Normalitas & $\begin{array}{l}\text { Kolmogorov- } \\
\text { Smirnov }\end{array}$ & $\begin{array}{l}\text { Sig pretest }=0,08 \\
\text { Sig postest }= \\
0,200\end{array}$ & $\mathrm{H}_{0}$ diterima & Data normal \\
\hline $\begin{array}{l}\text { Homogenitas } \\
\text { Hasil Pretest - } \\
\text { Posttest }\end{array}$ & $\begin{array}{l}\text { Levene's test } \\
\text { Paired } \\
\text { Sample t-test }\end{array}$ & $\begin{array}{l}\text { Sig }=0,532 \\
\text { thitung }=-8,194 \\
\mathrm{p}=0,000\end{array}$ & $\begin{array}{l}\mathrm{H}_{0} \text { diterima } \\
\mathrm{H}_{0} \text { ditolak }\end{array}$ & $\begin{array}{l}\text { Data Homogen } \\
\text { Hasil tidak } \\
\text { sama } \\
\text { beda) }\end{array}$ \\
\hline
\end{tabular}


Tabel 9. Hasil Data Gain dan N-Gain

\begin{tabular}{cccc}
\hline \multirow{2}{*}{ Jenis Data } & \multirow{2}{*}{ Gain } & Rata-Gain \\
\hline Keterampilan Proses Sains & 27 & 15,37 & 0,54 \\
\hline
\end{tabular}

Berdasarkan hasil dan nilai posttest seperti pada Gambar.1 penelitian dapat dibuat histogram dan perbandingan persentase penilain rata-rata perbandingan KPS pretest aspek KPS pada Gambar 2.

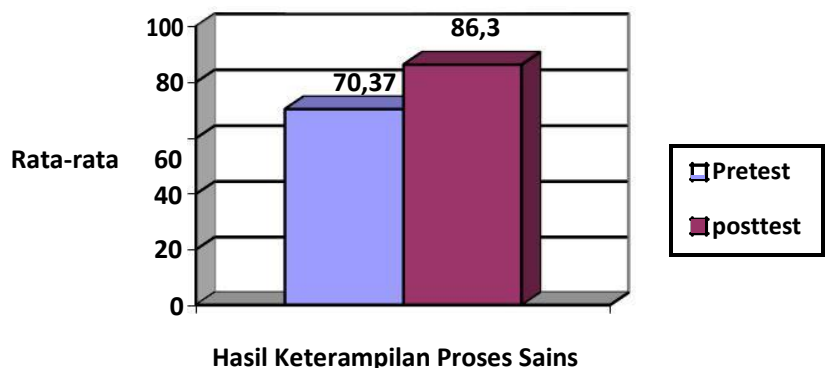

Gambar 1. Histogram Perbandingan Nilai Rata-rata KPS Pretest-Posttest

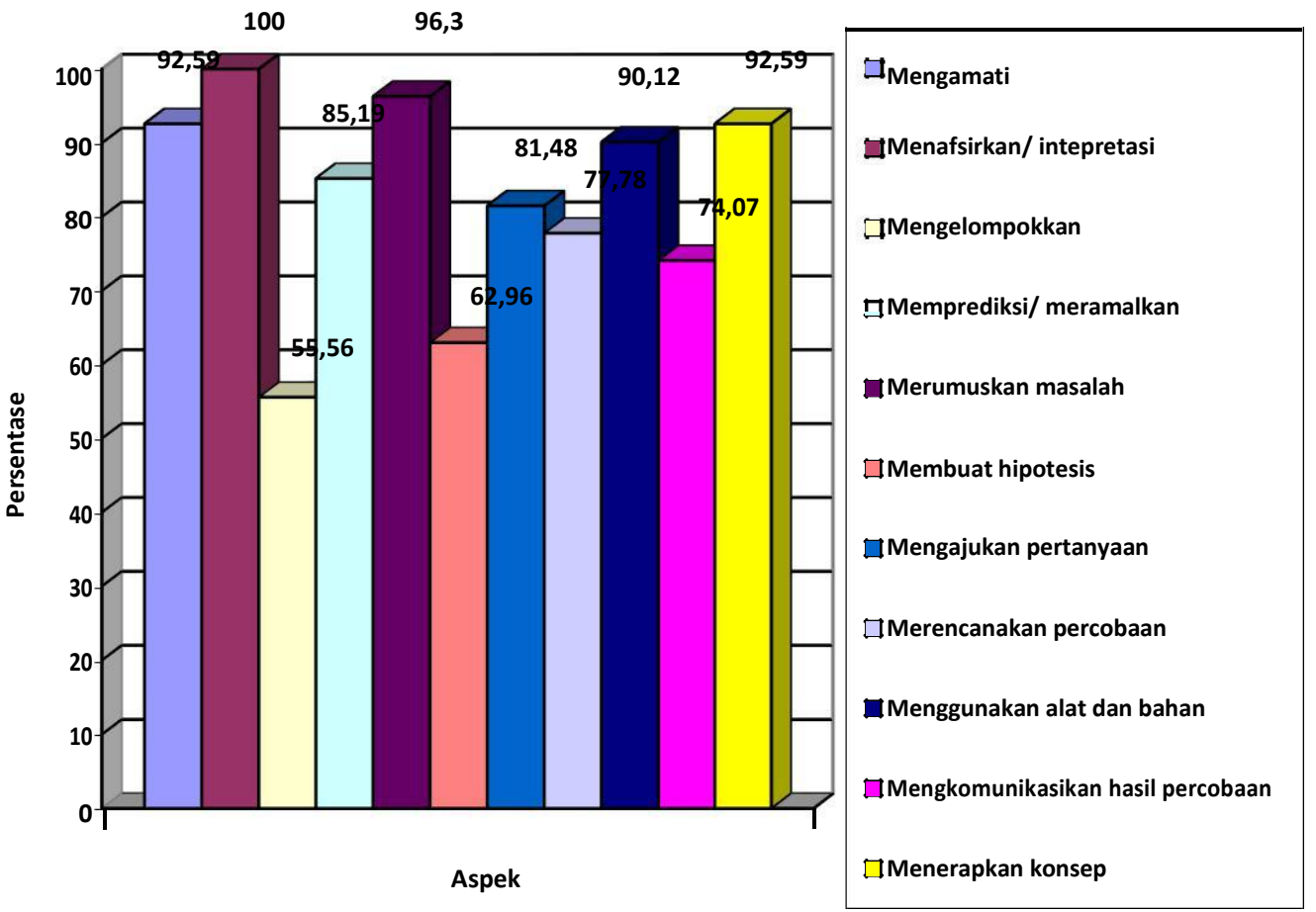

Gambar. 2 Histogram Perbandingan Persentase Penilaian Aspek KPS 


\section{Pembahasan}

Data nilai pretes dan posttest yang telah diketahui bahwa distribusinya normal dan homogen selanjutnya dianalisis dengan uji lanjut berupa uji Paired Sample t-test (Uji t dua sampel berpasangan) untuk mengetahui ada tidaknya efektivitas model pembelajaran STS disertai $M M$ dalam memberdaya kan KPS siswa. Berdasarkan perhitungan menggunakan uji lanjut Paired Sample t-test diperoleh thitung sebesar -8,194 dengan probabilitas sebesar $0,000(\mathrm{p}<0,05)$, maka $\mathrm{H}_{0}$ ditolak sehingga dapat dinyatakan bahwa ada perbedaan antara nilai KPS siswa sebelum dan sesudah diberikan model pembelajaran STS disertai MM. Berdasarkan hasil tersebut dapat disimpulkan bahwa pembelajaran menggunakan model pembelajaran berbasis STS disertai $M M$ pada materi pencemaran lingkungan dapat memberdayakan KPS siswa.

Hasil uji menunjukkan nilai peningkatan $N_{\text {gain }}$ berdasarkan kriteria Hake (1998) hasil KPS mengalami peningkatan dari hasil pretest dan posttest yang masuk dalam kriteria peningkatan kategori "Sedang". Kenaikan nilai yang berada pada kategori sedang berati menandakan ada perbedaan antara hasil pretest dan posttest. KPS diukur berdasarkan aspek penyusunnya yang terdiri dari 11 aspek. Aspek tertinggi berada pada aspek menafsirkan atau interpretasi. Pada aspek ini siswa dilatihkan untuk mencatat hasil pengamatan kemudian mengungkap kan hasil yang diperoleh berdasarkan percobaan yang telah dilakukan. Aspek terendah berada pada aspek mengelompokkan, pada aspek ini siswa diarahkan untuk melakukan kegiatan mencari perbedaan, mengontras kan ciri-ciri, membandingkan dan mencari dasar penggolongan.

Pembelajaran dengan menggunakan model STS disertai $M M$ menekankan pada pembelajaran pemecahan masalah melalui penyelidikan untuk menemukan solusi dari permasalahan yang ada di masyarakat. Pembelajaran dilakukan dengan menggunakan kelompok. Siswa dikelompokkan secara heterogen agar kemampuan interaksi soasial akan muncul dan memunculkan kebiasaan sikap bekerja sama dengan teman. Melalui kerja kelompok siswa menjadi lebih mudah dalam berbagi pengetahuan dan bersamasama saling membantu menemukan konsep mealui penyelidikan. Hal ini sejalan dengan teori Vigotsky yang menekankan pentingnya interaksi sosial dengan orang lain yang mempunyai pengetahuan yang lebih baik dan sistem secara kultural telah berkembang dengan baik. Vygotsky memberi tempat yang lebih penting pada aspek sosial dengan teman lain memacu terbentuknya ide baru dan memperkaya perkembangan intelektual siswa, sehingga siswa perlu berinteraksi dengan para ahli baik didalam pembelajaran maupun pada kegiatan laboratorium. 
Bruner juga menyatakan bahwa dalam pembelajaran diperlukan adanya proses scaffolding. Scaffolding merupakan suatu proses untuk membantu siswa menuntaskan masalah tertentu melampaui kapasitas perkembangannya melalui bantuan guru, teman atau orang lain yang memiliki kemampuan lebih.

Pembelajaran dengan menggunakan model STS disertai $M M$ memberikan pengaruh positif pada kenaikan skor rata-rata, sehingga nilai rata-rata siswa setelah mengalami pembelajaran dengan model STS disertai $M M$ mengalami peningkatan. Melalui pembelajaran yang mengaitkan ilmu pengetahuan dan teknologi dengan masyarakat atau lingkungan membuat siswa aktif dalam kegiatan pembelajaran. Permasalahan yang ada di lingkungan yang dikemas sesuai dengan tahap STS disertai $M M$ sebagai teknik menyimpulkan kegiatan pembelajaran memberikan suatu model pembelajaran baru bagi siswa sehingga siswa memiliki antusias yang tinggi dalam mengikuti kegiatan pembelajaran. Kegiatan pembelajaran yang disusun mampu mengembangkan KPS siswa. Hal ini relevan dengan teori belajar Ausubel dimana pembelajaran yang dipelajari haruslah bermakna, proses bermakna terjadi apabila seseorang mampu mengasimilasikan pengetahuan yang telah dimiliki dengan pengetahuan baru. Sejalan dengan NSTA (2010) yang mengemukakan bahwa siswa akan termotivasi untuk mempelajari konsep dalam pembelajaran sains melalui serangkain proses sains apabila didahului oleh permasalahan yang mungkin pernah dialami oleh siswa dan kebanyakan orang sehingga siswa cenderung aktif mengembangkan KPS melalui kegiatan pembelajaran.

\section{E. Kesimpulan dan Saran}

Kesimpulan yang dipeoleh dari penelitian adalah model STS disertai $M M$ terbukti memiliki efektif untuk memberdayakan KPS diperoleh dari penilaian $N_{\text {gain }}$ yang memiliki nilai 0,54 yang berarti memiliki peningkatan dengan kategori "Sedang". Setelah dilakukan uji secara statistik diperoleh adanya perbedaan KPS siswa, sebelum dan setelah diterapkan model berbasis STS disertai $M M$ dengan hasil $\mathrm{p}=0,00$.

Saran dalam penelitian menggunakan model STS disertai $M M$ adalah menggunakan waktu dan mengelola kelas seefektif mungkin dalam mengajarkan materi dengan model pembelajaran STS disertai $M M$ agar sesuai rencana dan dapat digunakan sebagai salah satu alternatif dalam kebijakan pengembangan kurikulum sekolah, khususnya pada pembelajaran IPA di SMA.

\section{DAFTAR RUJUKAN}

Arikunto, S. 2006. Prosedur Penelitian Suatu Pendekatan Praktek. Jakarta: Rineka Cipta. 
Arikunto, S. 2010. Dasar-Dasar Evaluasi Pendidikan. Yogyakarta: Bumi Aksara.

BSNP. 2006. Standar Isi Mata Pelajaran IPA. Jakarta: Depdiknas.

Buzan, Tony. 2007. Buku Pintar Mind Map untuk Anak. Jakarta : PT Gramedia Pustaka Utama.

Darmadi, H. 2011. Metode Penelitian Pendidikan. Bandung: Alfabeta.

Depdiknas. 2006. Petunjuk Teknis Pengembangan Silabus dan Contoh Model Silabus SMA. Jakarta: BSNP.

Depdiknas. 2008. Perangkat Pembelajaran KTSP SMA. Jakarta: Direktorat Pembinaan Sekolah Menengah Atas.

Hake, RR. 1998. Interactive Engangement Versus Traditional Method: A SixThousand Student Survey of Mechanics Test Data for Introductory Phyics Course. Am. J. Phus. 66: 64-74.

Hyerle, D., \& Alper, Larry. 2012.

Peta Pemikiran Thinking Maps. Jakarta: PT Indeks.

Hyerle, D. 2009. Visual Tools for Constructing Knowledge. Thousand Oaks, CA: Corwin.

Joyce \& Well. 2000. Models of Teaching. USA: Allyn and Bacon.
Novak, J. D., \& Gowin, D. B. 2008. Learning How To Learn. New York: Cambridge University Press.

Nurohman, Sabar. 2009. Penerapan Pendekatan STM dalam Pembelajaran IPA sebagai Upaya Meningkatkan Lifeskills Peserta Didik. Diunduh dari http://www.chass.ncsu.edu/ids/sts tanggal 5 Juni 2014.

Poedjiadji, A. $2007 . \quad$ Model Pembelajaran Sains Teknologi Masyarakat. Bandung: Rosdakarya.

Pusat Penelitian Pendidikan Balitbang Kemdikbud. 2013. Survei Internasional PISA (Programme for International Student Assessment). Diperoleh 25 Februari 2012, dari http://litbang.kemdiknas.go.id/deta il.php.

Riduwan. 2004. Metode dan Teknik Menyusun Tesis. Bandung: Alfabeta.

Rustaman, N.Y., Dirdjosoemarto, S., Yudianto, S.A., Achmad, Y., Subekti, R., Rochintaniawati, D., \& Nurjhani, M. 2005. Strategi Belajar Mengajar Biologi. Bandung: UPI Press.

Suciati, 2010. Membangun Karakter Peserta Didik Melalui Pembelajaran Biologi Berbasis Keterampilan Proses. Proceeding Seminar Nasional VII Pendidikan Biologi FKIP UNS, 237-243. Surakarta: FKIP Universitas Sebelas Maret. 
Sudjana, N., \& Rivai, A. 2007. Media Pengajaran. Bandung: Sinar Baru Algesindo.

Sugiyono. 2010. Metode Penelitian Kuantitatif dan Kualitatif dan $R \& D$. Bandung: Alfabeta.

Syaodih Sukmadinata, Nana. 2012. Metode
Pendidikan. Bandung: Remaja Rosdakarya.

Trianto. 2010. Mendesain Model Pembelajaran Inovatif Progresif: Konsep, Landasana, dan Implementasinya pada Kurikulum Tingkat Satuan Pendidikan (KTSP). Jakarta: Kencana. 
